\title{
Kecepatan Pertumbuhan Mycobacterium tuberculosis pada media Ogawa dengan Bahan Dasar Telur yang Berbeda
}

\author{
Speed Growth of Mycobacterium tuberculosis on Ogawa Media with Different Eggs base material
}

\author{
Muhammad Evy Prastiyanto ${ }^{1 *}$, Sri Darmawati ${ }^{2}$, Iin Inayatul Karomah \\ ${ }^{1}$ Laboratorium Mikrobiologi,Program Studi Analis Kesehatan, Unimus \\ ${ }^{2}$ Laboratorium Biologi Molekuler,Program Studi Analis Kesehatan, Unimus \\ ${ }^{3}$ Program Studi D3 Analis Kesehatan, Unimus \\ *Corresponding author: evy prastiyanto@unimus.ac.id
}

\begin{abstract}
ABSTRAK
Tuberkulosis adalah penyakit infeksi menular, kronik dan dapat menyebabkan kematian yang disebabkan oleh Mycobacterium tuberculosis. Diagnosa tuberkulosis dilakukan dengan berbagai cara, salah satunya dengan kultur pada media Ogawa. Penelitian ini bertujuan untuk mengetahui kecepatan pertumbuhan M. tuberculosis pada media ogawa dengan bahan dasar telur puyuh, telur bebek, telur enthok, dan telur ayam kampung. Metode yang dilakukan yaitu sputum BTA 3+ yang didapatkan dari Balai Kesehatan Paru Masyarakat (BKPM) Semarang diolah dengan metode kubica, kemudian diinokulasi pada media ogawa dengan bahan dasar telur yang berbeda. Pengamatan kecepatan pertumbuham M. tuberculosis dilakukan setiap hari. Hasil penelitian menunjukan ada perbedaan yang signifikan pada ke empat telur terhadap pertumbuhan M. tuberculosis pada media ogawa. Hasil penelitian menunjukkan bahwa media ogawa dengan bahan dasar telur puyuh dan entok dapat menumbuhkan M. tuberculosis lebih cepat dibanding dengan bahan dasar telur ayam kampung dan telur bebek. Media ogawa berbahan dasar telur puyuh dan telur entok menunjukkan rata-rata waktu pertumbuhan tercepat yaitu 17 hari. Sedangkan bahan dasar telur ayam kampung 20-21 hari dan bahan dasar telur bebek 23-24 hari.
\end{abstract}

Kata kunci: Media Ogawa, Mycobacterium tuberculosis, pertumbuhan

\section{ABSTRACT}

Tuberculosis is a contagious, chronic infectious diseases and can cause deaths caused by Mycobacterium tuberculosis. Diagnosis of tuberculosis is done in various ways, one of them with culture media Ogawa. This research aims to know the speed of the growth of M. tuberculosis in the media base material with ogawa quail eggs,duck eggs, barbary duck eggs, and local chicken eggs. Methods undertaken i.e. sputum BTA 3 + of Balai Kesehatan Paru Masyarakat (BKPM) Semarang processed kubica method, then inoculated on the media base material with ogawa egg. Observations of the speed growth M. tuberculosis is done every day. Results of the study showed there was a significant difference in the four eggs against the growth of M. tuberculosis in media ogawa. The results showed that the media base material with ogawa quail eggs and barbary duck can grow m. tuberculosis more quickly than with the basic ingredients of local chicken eggs and duck eggs. Media ogawa-quail eggs and barbary duck eggs shows average time fastest growth that is 17 days. While the basic ingredients of local chicken eggs 20-21 day and the basic ingredients of duck eggs 23-24 day.

Keywords : Ogawa Media, Micobacterium tuberculosis, Growth

\section{PENDAHULUAN}

Tuberkulosis adalah penyakit infeksi menular, kronik dan dapat menyebabkan kematian. Menurut Budhiyani et al., (2011) tuberculosis merupakan penyakit dengan angka kesakitan dan kematian yang tinggi di berbagai Negara, termasuk Indonesia. Diperkirakan setiap tahun lebih dari 8 juta kasus baru tuberkulosis dan sekitar 3 juta orang meninggal (WHO, 1996). Jadi Tuberkulosis adalah penyakit yang berbahaya dan menyebabkan kematian. Sembilan puluh lima persen kasus tuberkulosis terjadi di negara berkembang (Locke et al., 2013), termasuk Indonesia.

Tuberkulosis dapat menular ketika penderita batuk, bersin atau berbicara (Leboffe dan Pierce, 2011). Menurut William dan Wilkins (2004) keti- 
ka batuk penderita tuberkulosis akan mengeluarkan droplet sebanyak 3.000. Droplet ini mengandung bakteri Mycobacterium tuberculosis penyebab penyakit tuberkulosis (Lew et al., 2011). Bakteri ini merupakan bakteri patogen, sehingga banyak penelitian dilakukan terhadap bakteri ini.

Bakteri M. tuberculosis dapat diketahui morfologi koloni serta uji kepekaan terhadap berbagai antibiotik ketika dikultur pada media padat. Media yang umum digunakan untuk kultur M. tuberculosis adalah Loweinstein Jensen, $\mathrm{Ku}$ doh dan Ogawa (Kudoh dan Kudoh, 1974). Media ogawa lebih sederhana dan murah dibanding dengan media lain. Bahan utama media ogawa adalah telur (Kudoh \& Kudoh, 1974). Umumnya telur yang digunakan adalah telur bebek dengan masa inkubasi selama 6-8 minggu. Pertumbuhan bakteri dipengaruhi oleh beberapa faktor yaitu suhu, $\mathrm{pH}$, tekanan osmosis, oksigen dan nutrisi (Pratiwi, 2008). Nutrisi yang digunakan dalam media harus tinggi sehingga dapat mempercepat pertumbuhan bakteri, sehingga memerlukan waktu inkubasi yang lama. Oleh sebab itu diperlukan modifikasi dalam penggunaan telur, misalnya telur puyuh, telur entok dan telur ayam kampung untuk mempercepat waktu inkubasi dari $M$. tuberculosis

\section{BAHAN DAN METODE}

\section{Pengolahan Sputum}

Sputum BTA 3+ yang didapatkan dari Balai Kesehatan Paru Masyarakat (BKPM) Semarang diolah secara homogenisasi dengan metode kubica yaitu sampel sputum dituang ke dalam tabung centrifuge. Ditambah $\mathrm{NaOH} 4 \%$ dengan perbandingan 1:1. Kemudian disentrifugasi dengan kecepatan 3000 rpm selama 15 menit. Filtrat hasil sentrifugasi dibuang, sedangkan endapannya ditambah $\mathrm{NaOH} 4 \%$ dengan perbandingan 1:1. Endapan yang telah ditambahn $\mathrm{NaOH}$ 4\% disentrifugasi dengan kecepatan $3000 \mathrm{rpm}$ selama 15 menit. Filtrat dibuang dan endapannya ditambah $\mathrm{NaCl}$ fisiologis, lalu dihomogenkan.

\section{Pembuatan Media Ogawa dengan Bahan Da- sar Telur yang Berbeda}

Telur puyuh, telur bebek, telur entok, dan telur ayam kampung dibersihkan dari kotoran dengan cara dicuci dengan sabun kemudian dibersihkan dengan alkohol $70 \%$. Telur dipecah dalam kondisi steril, alat-alat yang digunakan harus steril. Telur dikocok supaya homogen, telur disaring dari buih dengan cara dituang ke beker glass steril di dekat pembakar spirtus sebanyak dua kali hingga buihnya hilang. Kocokan telur ditambah larutan garam sebanyak $100 \mathrm{~mL}\left(\mathrm{KH}_{2} \mathrm{PO}_{4} 3 \mathrm{~g}\right.$, sodium glutamat $1 \mathrm{~g}$ dan aquadest $100 \mathrm{~mL}$ ), $\mathrm{ma}$ lachite green $2 \%$ sebanyak $6 \mathrm{~mL}$ dan glycerol $6 \mathrm{~mL}$ lalu dihomogenkan. Selanjutnya media dituang ke tabung reaksi sekitar 7-8 mL. Media disterilkan dengan cara tyndalisasi dengan posisi tabung miring.

\section{Penanaman Bakteri pada Media Ogawa}

Media ogawa yang sudah steril disiapkan. Suspensi dipipet sebanyak $100 \mu \mathrm{L}$ dan diteteskan pada media ogawa. Media diinkubasi dengan posisi miring selama $2 \times 24$ jam pada suhu $37^{\circ} \mathrm{C}$, kemudian diposisikan tegak dan diinkubasi $37^{\circ} \mathrm{C}$ selama delapan minggu.

\section{Pengamatan Pertumbuhan Mycobacterium tuberculosis}

Pengamatan dilakukan setiap hari dengan melihat pertumbuhan koloni $M$. tuberculosis pada media ogawa telur puyuh, telur bebek, telur entok, dan telur ayam kampung kemudian membandingkan semuanya.

\section{HASIL}

Waktu rata-rata pertumbuhan $M$. tuberculosis pada media ogawa berbahan dasar telur puyuh, telur bebek, telur entok dan telur ayam kampung disajikan pada Tabel 1. Hasil penelitian menunjukan waktu pertumbuhan M. tuberculosis pada media ogawa dengan bahan dasar telur puyuh dan telur entok rata-rata tumbuh sama pada hari 
ke-17, sedangkan pada media ogawa bahan dasar telur bebek dapat menumbuhkan M. tuberculosis rata-rata pada hari ke 23-24 dan pada media ogawa bahan dasar telur ayam kampung dapat menumbuhkan $M$. tuberculosis rata-rata pada hari ke- 20-21. Hal ini berarti kecepatan pertumbuhan M.tuberculosis yang paling cepat yaitu pada media ogawa telur puyuh dan telur entok, kemudian diikuti telur ayam kampung dan yang paling lambat yaitu media ogawa telur bebek.

Hasil pengamatan kecepatan pertumbuhan M. tuberculosis pada ke empat telur bahan dasar media ogawa tampak pada Gambar 2.

Jenis telur yang digunakan sebagai bahan dasar media ogawa, masing-masing memiliki warna yang berbeda-beda karena telur kuning yang dimiliki berbeda pula warnanya. Koloni bakteri M. tuberculosis pada media tersebut berukuran sangat kecil berbentuk bulat kering, berwarna kuning dengan konsistensi kasar. Jumlah koloni sama secara visual dapat dilihat pada ke empat media ogawa. Pada telur puyuh dan telur entok jumlah koloni yang sama diantara ke empat me- dia yaitu pada hari ke-37, sedangkan pada media ogawa ayam kampung pada hari ke-40 dan media ogawa telur bebek pada hari ke-43.

\section{PEMBAHASAN}

Diagnosis tuberkulosis dapat ditegakkan dengan beberapa metode antara lain: preparat ulas dahak menggunakan pewarnaan asam, uji tuberculin, uji gamma interferon, uji proliferasi limfosit, enzyme linked immunosorbant assay (ELISA) dan Polymerase Chain Reaction (PCR). Akan tetapi diagnosis definitif terhadap tuberkulosis hanya dapat dilakukan dengan kultur M. tuberculosis. (OIE, 2009; Parsons et al., 2011). Banyak media yang dirancang untuk kultur basil tuberkel dan diidentifikasi dalam tiga kelompok utama, yaitu media yang berbasis telur, media berbasis agar dan media cair. Media yang ideal untuk isolasi basil tuberkel harus ekonomis dan sederhana, dapat menghambat pertumbuhan kontaminan, dan mendukung pertumbuhan sejumlah kecil basil. Kultur spesimen sputum, media berbasis telur harus menjadi pilihan utama karena

Tabel 1. Waktu Rata-Rata Pertumbuhan M. tuberculosis pada media Ogawa dengan bahan dasar telur yang Berbeda Bahan dasar Telur Media Ogawa Waktu pertumbuhan M. tuberculosis (hari)

\begin{tabular}{lc}
\hline Telur puyuh & 17 \\
Telur bebek & 23.5 \\
Telur entok & 17 \\
Telur ayam kampung & 20.1 \\
\hline
\end{tabular}
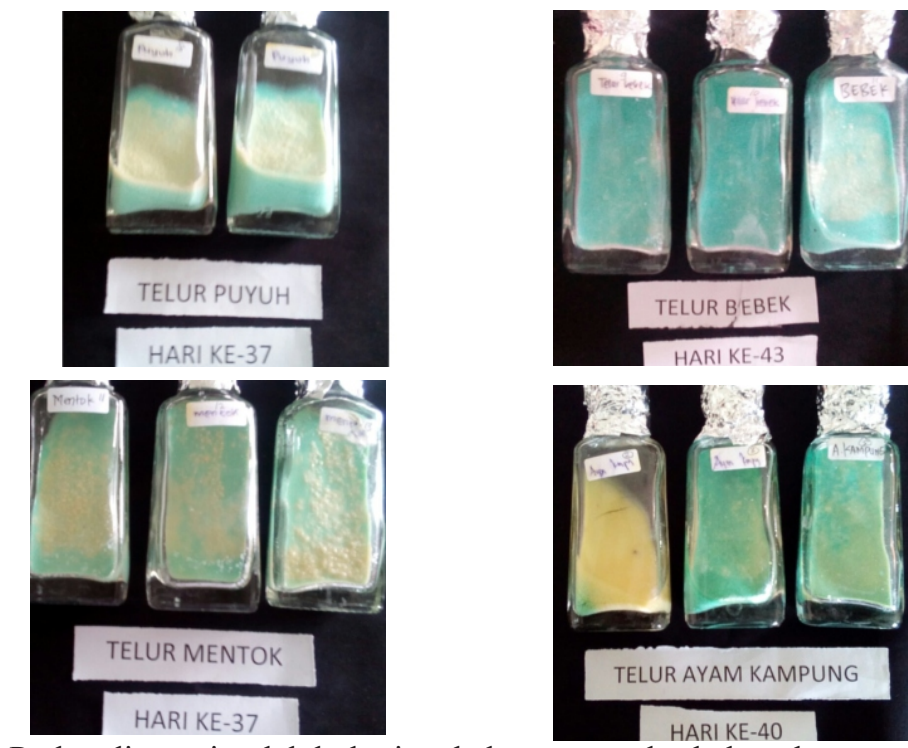

Gambar 3. Perbandingan jumlah koloni pada ke empat telur bahan dasar media ogawa 
memenuhi semua persyaratan. Media tersebut di antaranya yaitu media ogawa.

Sampel yang digunakan sebagai bahan dasar media ogawa dalam penelitian ini adalah telur puyuh, telur bebek, telur entok dan telur ayam kampung. Hasil pertumbuhan M. tuberculosis pada media ogawa bahan dasar telur puyuh dan telur entok menunjukan rata-rata bakteri tumbuh pada hari ke- 17 , sedang pada media ogawa telur ayam kampung bakteri rata-rata tumbuh pada hari ke- 20-21, begitu juga pada media ogawa telur bebek bakteri rata-rata tumbuh pada hari ke- 23-24. Berdasarkan hasil statistik dengan menggunakan uji Kruskal Wallis ada perbedaan yang signifikan pada ke empat telur terhadap pertumbuhan M. tuberculosis pada media ogawa. Berdasarkan uji Post Hoc terdapat perbedaan yang signifikan antara telur puyuh dan telur bebek, antara telur puyuh dan telur ayam kampung, antara telur bebek dan entok, antara telur bebek dan ayam kampung. Sedangkan antara telur puyuh dan telur entok tidak ada perbedaan yang signifikan. Hal ini dikarenakan terdapat jumlah kandungan nutrisi yang berbeda antara ke empat telur (Chen, 1996). Faktor yang mempengaruhi pertumbuhan bakteri diantaranya adalah suhu, $\mathrm{pH}$, tekanan osmosis, oksigen dan nutrisi (Pratiwi, 2008), akan tetapi pada penelitian ini dilakukan perlakuan yang sama terhadap kedua sampel, baik dari suhu, $\mathrm{pH}$, tekanan osmosis oksigen maupun waktu inkubasi, yang membedakan hanya pada kandungan nutrisi dari sampel sendiri.

Nutrisi yang dibutuhkan M. tuberculosis di antaranya adalah besi, kalium, magnesium, carbon, hidrogen, oksigen dan nitrogen. Selain faktor di atas protein merupakan nutrisi utama yang dibutuhkan M. tuberculosis untuk pertumbuhannya (Srigede et al., 2013). Molekul protein mengandung unsure-unsur $\mathrm{C}, \mathrm{H}, \mathrm{O}$, dan N. Selain itu protein juga mengandung unsur belerang, fosfor, serta logam seperti seng dan besi (Tull, 1996), sehingga semua unsur yang dibutuhkan bakteri ada pada protein. Oleh karena itu media yang digunakan untuk kultur M. tuberculosis adalah me- dia dengan bahan dasar utamanya telur sebagai sumber protein.

Telur puyuh, telur bebek, telur entok dan telur ayam kampung yang digunakan sebagai bahan pada media ogawa mempunyai kandungan nutrisi yang dibutuhkan M. tuberculosis baik dari sumber mikronutrien maupun makronutrien, sehingga keempatnya dapat menumbuhkan bakteri tersebut. Akan tetapi waktu yang diperlukan untuk menumbuhkan bakteri $M$. tuberculosis berbeda. Hal ini dimungkinkan karena jumlah kandungan nutrisi pada ke empat telur tersebut berbeda. Bakteri dapat tumbuh pada media yang mempunyai kandungan nutrisi yang sesuai (Atlas, 2004), dapat tumbuh lebih cepat pada media yang mempunyai kadar kandungan nutrisi yang dibutuhkan lebih optimal.

Bahan utama media ogawa adalah telur, karena dalam telur mengandung albumin yang tinggi. Menurut Ratledge (2007), albumin mengandung transferin dan ovoferin (ovotransferin), yaitu molekul pengikat besi. Struktur tersebut biasanya mengandung residu hidroksi asam benzoat atau dihidroksi benzoat. Residu tersebut meliputi mikobaktin dan karboksimikobaktin, yang ditemukan pada mikobakteri patogen. Kompleks siderofera-besi memasuki amplop, masuk ke dalam membran sel bakteri, di tempat Fe(III) biasanya direduksi menjadi Fe(II). Dengan begitu semakin banyak kandungan albumin dalam media semakin cepat pula pertumbuhan bakteri $M$. tuberculosis pada media tersebut.

Komponen struktural bakteri terdiri dari protein, dimana protein digunakan sebagai penyusun dinding sel dan enzim, sedangkan enzim digunakan untuk aktivitas metabolisme yang kemudian hasil metabolisme itu digunakan untuk aktivitas kehidupan, sehingga ketika protein tidak disintesis maka enzim tidak tersedia, metabolisme tidak berlangsung dan bakteri mati. Dengan begitu protein sangat berpengaruh terhadap kelangsungan hidup bakteri dan kadar protein dalam media berpengaruh terhadap kecepatan pertumbuhan bakteri (Srigede et al., 2013), se- 
hingga waktu pertumbuhan bakteri $M$. tuberculosis pada media ogawa telur puyuh dan telur entok paling cepat diantara ke empat telur. Hal ini dikarenakan telur puyuh mengandung protein lebih tinggi dibanding telur bebek yaitu sebanyak $13,35 \%$ sedangkan telur bebek mengandung pro tein sebanyak 12,81\% (Chen, 1996).

\section{DAFTAR PUSTAKA}

Atlas, Ronald M. 2004. Handbook of Microbiological Media fourth Edition Volume 1. United States of America: CRC Press.

Budhiyani, N.S.D., Parwati I., Alisjahbana B., Turbawaty DK ., 2011. Kesesuaian antara Metode Microscopic Observation Drug Susceptibility Assay dan Ogawa pada Biakan Mycobacterium tuberculosis Conformity Method Between Microscopic Observation Drug Susceptibility Assay and Ogawa Mycobacterium Culture. , 43(2), pp.83-88

Kudoh, S. \& Kudoh, T. 1974. A simple technique for culturing tubercle bacili. Bull. Org. mond. Stand \& Bull. Wld Hith Org. 51: 71-82.

Leboffe, Michael J \& Pierce, Burton E. 2011. A photographic atlas for the microbiology laboratory,
Lew, J.M., Kapopoulou, A., Jones, L.M., \& Cole, S.T. 2011. Tuberculist-10 years after. Tuberculosis (Edinb). 91: 1-7

Locke, T., Keat, S., Walker, A. dan Mackinnon R. 2013. Microbiology and Infectious Disease on the Move. Diterjemahkan oleh : dr. Rizqi Akbarini, Tim Indeks, Jakarta.

Office Internasional des Epizooties [OIE]. 2009. Bovine Tuberculosis. Dalam: OIE Terestrial Manual. Paris: OIE. Hlm. 1-16.

Parsons LM, Somoskovi A, Gutierrez C, Lee E, Paramasivan CN, Abimiku A, Spector S, Roscigno G, Nkengasong J. 2011. Laboratory diagnosis of tuberculosis in resource-poor countries: challenges and opportunities. Clin Microbiol Rev 24(2): 314-350.

Pratiwi, S. T. 2008. Mikrobilogi Farmasi. Erlangga. Jakarta

Ratledge C. 2007. Iron metabolism and infection. Food and Nutr Bulletin 28(4) suppl: S515-S523.

Srigede, L., Zaetun, S., Getas, I.W .2013. Perbedaan Pertumbuhan Mycobacterium tuberculosis pada media agar nutrien dengan penambahan tepung cacing tanah (Lumbricus rubellus) dibandingkan dengan pertumbuhan pada media Loweinstein Jensen. ,7(1978).

Tull, A. 1996. Food and Nutrition. Oxford University Press. New York, pp: 9-11, 92-94.

World Health Organization, 1996. Groups at Risk: WHO Report on the Tuberculosis Epidemic. World Health Organization, Geneva, Switzerland. http://apps.who.int/iris/bitstream/ 10665/67890/3/WHO_TB_97.220_tha.pdf diakses pada tanggal 22 Desember 2015. 